\title{
Homoeopathic treatment leading to a unique response in a patient with renal cell carcinoma
}

\author{
Nilanjana Basu \\ Medical Director, Just Homoeopathy, Greater Noida, Delhi, India
}

\section{KEY WORDS}

\section{Solid renal mass}

Renal cell carcinoma

Homoeopathy

Fifty millesimal potency

Quality of life

\section{*Corresponding Author:}

Nilanjana Basu

Just Homoeopathy

Greater Noida

Contact no: +91-9810699298

E-mail: niil2007@yahoo.co.in

\begin{abstract}
A 45-year-old male patient presented with bilateral solid renal mass probably renal cell carcinoma (RCC). After initial treatment, the patient got symptomatic relief from pain in flanks, acute retention of urine and hematuria. The patient initially declined repeated investigations but agreed for an ultrasound after two years of treatment; the result showed reduction in size of the mass. The urea, creatinine and hemoglobin percentage were normal and reported a normal blood pressure. The quality of life was maintained without the conventional surgery, radiotherapy, chemotherapy, or immunotherapy. While this case provides evidence of positive outcomes for homeopathic therapy, more studies are required in a hospital setting to establish the real extent to which this therapy may be employed.
\end{abstract}

doi: 10.38205/imcr.010219

\section{Introduction}

Due to advancement of imaging techniques, diagnosis of renal masses has increased since past two decades. They are usually 'incidentally' found during USG done for other conditions. Solid renal masses are usually Renal Cell Carcinoma (RCC) (1). The increase in tumor size decides the significant malignancy in it $(2,3)$. Confirm diagnosis can be done by biopsy which is accurate in $72 \%$ cases as compared to computed tomography scan, whose accuracy is $60 \%$ (4). But study shows that needle biopsies are detrimental to patients so it may be avoided (5).

Symptomatology of RCC includes hematuria in 35-60\% cases (6) dullness in loin and clot colic. Males are generally more affected than females. Prognosis can depend on the age of the patient, presence of hematuria and size of the renal mass $(2,3)$.

Treatment for RCC is usually surgical i.e. partial or radical nephrectomy. In 3\% cases cancer-specific deaths occur during follow-up $(6,7)$.

In homoeopathy, there are in vitro studies that suggest the effect of homoeopathic medicines in regression of malignant cells of kidney (8). This case of bilateral solid renal mass probably RCC, treated with individualized homoeopathic medicine given in fifty millesimal potency, is presented to add documentary evidence in the literature.

\section{Case presentation}

A 45-years-old male patient presented with bleeding per urethra in the past 15 days. The blood was mixed with the urine throughout. The patient had similar episodes of bleeding per urethra followed by retention of urine due to clots which was relieved by catherization. There was history of passing clots in urine. He complained of pain in lower part of abdomen for two days. There was no radiation or extension of the pain. Patient passed urine with difficulty. He also had recurrent dull aching pains in the loins. His pain first appeared on the right side followed by the left loin. Patient noticed a swelling in left loin gradually increasing in size. He had history of hypertension for four years and was under medication. Patient complained of distension of abdomen recurrently which was not relieved by flatus.

There was no significant past-history recorded in the patient. The patient had a strong family history of polycystic kidney disease in the paternal family. All parameters were found normal while doing general physical examination. On inspection, there was fullness of the left flank which confirmed to be a non-tender mass on bimanual palpation. Systemic examination revealed no abnormalities. Physical general symptoms were taken according to homoeopathic principles, with findings like flatulence if he does not eat for long. He desired salty and lukewarm food. He had thirst for large quantities of water. His tongue had a thick fur like white coating. He passed urine which was mixed with blood. Patient was mild in nature. He was forgetful in the last 1-2 years. He becomes sentimental and sad by the thought of his family after his death. On observation, he seemed to be lost in thoughts. Every time any question was asked, he answered after a long pause, seemed to be lost somewhere. On asking he replied that he was thinking. 


\section{Special Investigations}

Ultrasonography (USG) of abdomen as on 14/06/2014 suggested bilateral renal space occupying lesion possibly RCC.

Contrast Enhanced Computed Tomography (CECT) scan report as on 17/06/2014 suggested heterogeneous soft tissue masses seen in lower halves of bilateral kidneys. Both the lesions are well encapsulated \& show areas of necrosis/cystic degeneration. Total GFR was $71.1 \%$ as on $23 / 06 / 2014$.

Patient was planned for right-sided partial nephrectomy followed by radiotherapy and so underwent anesthetic checkup on $07 / 07 / 2016$ in a reputed government hospital. Patient refused to undergo operation and radiotherapy so consulted for homoeopathic treatment.

\section{Repertorization}

According to the homoeopathic principles, this case was repertorized with the help of complete repertory and the following rubrics were taken (Table 1 ).
- [Complete] [Kidneys] General

- [Complete] [Abdomen] Distension

- [Complete] [Rectum] Flatus

- [Complete] [Generalities] Food and drinks: Salt or salty food: Desires

- [Complete] [Mouth] Coated: White: Tongue

- [Complete] [Mind] Forgetfulness

- [Complete] [Mind] Sentimental

- [Complete] [Mind] Absorbed, buried in thought

\section{Selection of Remedy}

Out of all the medicines arriving after repertorization, Antimonium crudum was the most similar to this case presentation. In this case, the tongue has a very prominent symptom for prescription. In repertory, though Pulsatilla nigricans had equal grade as Antimonium crudum, the materia medica suggests, the thickly white coating of the tongue is a red strand of the remedy, Antimonium crudum (9). The combination of the

Table 1: Repertorization Chart

\begin{tabular}{|l|c|c|c|c|c|c|c|c|c|}
\hline Remedy & Nat-m & Sulph & Phos & Cocc & Nit-ac & Sep & Puls & Verat & Ant-c \\
\hline Totality & 29 & 29 & 27 & 26 & 26 & 26 & 26 & 26 & 25 \\
\hline Symptoms covered & 8 & 8 & 8 & 8 & 8 & 8 & 7 & 7 & 8 \\
\hline [Kidneys] General: & 4 & 4 & 4 & 4 & 4 & 4 & 4 & 4 & 4 \\
\hline [Abdomen] Distension: & 4 & 4 & 4 & 4 & 4 & 4 & 4 & 4 & 4 \\
\hline [Rectum] Flatus: & 4 & 4 & 4 & 4 & 4 & 4 & 4 & 4 & 4 \\
\hline [Generalities] Food and drinks: & 4 & 3 & 4 & 1 & 4 & 3 & 0 & 4 & 1 \\
Salt or salty food: Desires: & & & & & & & & 4 \\
\hline [Mouth] Coated: White: Tongue: & 3 & 3 & 3 & 3 & 3 & 3 & 4 & 3 & 4 \\
\hline [Mind] Forgetfulness: & 4 & 4 & 4 & 4 & 4 & 4 & 4 & 4 & 3 \\
\hline [Mind] Sentimental: & 3 & 3 & 3 & 3 & 1 & 3 & 3 & 0 & 4 \\
\hline [Mind] Absorbed, buried in thought: & 3 & 4 & 1 & 3 & 2 & 1 & 3 & 3 & 1 \\
\hline
\end{tabular}

typical mental symptoms like sentimental, physical generals like thickly white coated tongue and particulars like distension of abdomen serves as the concomitant to the renal case. Though the other medicines had more marks, after consulting the materia medica, Antimonium crudum was the choice of remedy and was given in fifty millesimal potency and regular follow ups were done (Table 2).

The patient refused to undergo further investigations after the homoeopathic treatment started. However, he was convinced for a USG after a gap of two years. The USG report suggested reduction in size of the mass. The size of the Renal mass is assessed in the table below (Table 3).

\section{Discussion}

The patient came with the complaint of hematuria, pain in lower part of abdomen, dullness in loin, and distension of abdomen. He had a strong family history of polycystic kidney disease. But he was diagnosed as having bilateral solid renal mass probably RCC as the size of the masses were more than $40 \mathrm{~mm}$. He was advised for partial nephrectomy followed by radiotherapy, but he refused to undergo surgery or any type of interventions like biopsy. Hence, he sorted for homoeopathic treatment. Antimonium crudum was given in fifty millesimal potency as it required a frequent repetition in the minutest doses. He was better symptomatically after starting the treatment and there was marked reduction in size of the mass of left kidney and all the complaints of the patient subsided eventually after 2 years. In RCC, the patients usually suffer from paraneoplastic signs and symptoms like anorexia, anemia, weight loss and hypertension $(10,11)$, which was not seen in this case. The liver and kidney function tests were favorable with no increase in urea and creatinine was noted. The hemoglobin percentage was also normal. Routine urine investigation does not have any significant abnormalities. The patient felt healthy, has a good appetite and further rapid progression of 
Table 2: List of the first and follow-up visits with details about the symptoms, CECT scan/USG report and laboratory findings and the prescribed medicine

\begin{tabular}{|c|c|c|c|c|}
\hline Date & Symptoms & CECT/USG report & Laboratory findings & Medicines prescribed \\
\hline 09/08/2014 & $\begin{array}{l}\text { - Hematuria } \\
\text { - Pain in lower part of umbilicus } \\
\text { - Dull pain in loin } \\
\text { - Distension of abdomen }\end{array}$ & $\begin{array}{l}\text { Rt. Kidney-55 × 55 × } 46 \mathrm{~mm} \\
\text { Lt. Kidney-85 ×69 ×61 mm } \\
\text { As on } 17 / 06 / 2014\end{array}$ & $\begin{array}{l}\text { Urea- } 19.3 \mathrm{mg} / \mathrm{dL} \\
\text { Creatinine- } 1.12 \mathrm{mg} / \mathrm{dL} \\
\text { As on } 16 / 06 / 2014\end{array}$ & $\begin{array}{l}\text { Antimonium crudum } \\
0 / 1 \text { tds }\end{array}$ \\
\hline $23 / 08 / 2014$ & $\begin{array}{l}\text { - No hematuria } \\
\text { - Distension better }\end{array}$ & & & $\begin{array}{l}\text { Antimonium crudum } \\
0 / 2 \text { tds }\end{array}$ \\
\hline $24 / 09 / 2014$ & $\begin{array}{l}\text { - No hematuria } \\
\text { - Mild pain in lower part of umbilicus } \\
\text { - Stool unsatisfactory }\end{array}$ & & $\begin{array}{l}\text { Urea-32.10 mg/dL } \\
\text { Creatinine- } 1.10 \mathrm{mg} / \mathrm{dL} \\
\text { As on } 08 / 09 / 2014\end{array}$ & $\begin{array}{l}\text { Antimonium crudum } \\
0 / 3 \text { tds }\end{array}$ \\
\hline $27 / 10 / 2014$ & $\begin{array}{l}\text { - Hematuria with mild burning pain } \\
\text { in urethra } \\
\text { - No pain in lower part of umbilicus } \\
\text { - Salivation increased } \\
\text { - Stool satisfactory } \\
\text { - Will power increased } \\
\end{array}$ & & & $\begin{array}{l}\text { Antimonium crudum } \\
0 / 4 \text { bd }\end{array}$ \\
\hline $25 / 11 / 2014$ & $\begin{array}{l}\text { - No hematuria } \\
\text { - Passed bits of tissue per urethra } \\
\text { - Pain abdomen } \\
\text { - Distension relapse } \\
\text { - Stool satisfactory } \\
\end{array}$ & & & $\begin{array}{l}\text { Antimonium crudum } \\
0 / 4 \mathrm{bd}\end{array}$ \\
\hline $23 / 12 / 2014$ & $\begin{array}{l}\text { - Hematuria absent } \\
\text { - Pain in loins } \\
\text { - Pain in epigastrium } \\
\end{array}$ & & & No medicine \\
\hline $15 / 04 / 2015$ & $\begin{array}{l}\text { - Hematuria absent } \\
\text { - Headache } \\
\text { - Distension relapse }\end{array}$ & & & $\begin{array}{l}\text { Antimonium crudum } \\
0 / 1 \text { tds }\end{array}$ \\
\hline $24 / 07 / 2015$ & $\begin{array}{l}\text { - Hematuria absent } \\
\text { - Passed bits of tissue per urethra } \\
\text { - No headache } \\
\text { - No distension }\end{array}$ & & $\begin{array}{l}\text { Urea-26.80 mg/dL } \\
\text { Creatinine- } 1.30 \mathrm{mg} / \mathrm{dL}\end{array}$ & $\begin{array}{l}\text { Antimonium crudum } \\
0 / 3 \text { tds }\end{array}$ \\
\hline $18 / 08 / 2016$ & $\begin{array}{l}\text { - Hematuria \& passage of bits of } \\
\text { tissue absent } \\
\text { - No distension } \\
\text { - No pain in loins } \\
\end{array}$ & $\begin{array}{l}\text { Rt. Kidney- } 51 \times 42 \times 42 \mathrm{~mm} \\
\text { Lt. Kidney- } 12 \times 11.2 \times 10.7 \mathrm{~mm} \\
\text { As on } 16 / 08 / 2016\end{array}$ & $\begin{array}{l}\text { Urea- } 23.70 \mathrm{mg} / \mathrm{dL} \\
\text { Creatinine- } 1.10 \mathrm{mg} / \mathrm{dL} \\
\text { As on } 16 / 08 / 2016\end{array}$ & $\begin{array}{l}\text { Antimonium crudum } \\
0 / 3 \text { tds }\end{array}$ \\
\hline
\end{tabular}

Table 3: Analysis of the size of the Renal mass after two years of treatment

\begin{tabular}{|l|l|l|}
\hline Date & Right kidney & Left kidney \\
\hline $17 / 06 / 2014$ & $55 \times 55 \times 46 \mathrm{~mm}$ & $85 \times 69 \times 61 \mathrm{~mm}$ \\
\hline $16 / 08 / 2016$ & $51 \times 42 \times 42 \mathrm{~mm}$ & $12 \times 11.2 \times 10.7 \mathrm{~mm}$ \\
\hline
\end{tabular}

the renal mass formation is restricted with only homeopathic treatment, which is always evident otherwise. This case also proves the fact that the constitutional treatment gives good result in critical diseases like renal mass probably RCC.

\section{Conclusion}

Medicines selected on characteristic symptoms by individualization, the unique homeopathic approach, has capability of giving encouraging results in dreaded diseases like RCC. More research is required in the form of randomized clinical trials. This case shows that the patients who are unwilling or unfit for surgical interventions can be treated with homoeopathy.

\section{Acknowledgement}

The author acknowledges the help of the patient in consenting to publish the case details. The author would like to thank Dr. Rajinder Singh for the inspiration to complete this work.

\section{Authorship contribution}

NB led the work from its conception to completion together with diagnosis and prescription of treatment plan with dosage and duration of therapy along with intermediate reviews.

\section{Source of funding}

No funding done for the paper. 


\section{Informed consent}

Informed consent was obtained from the patient before writing this paper.

\section{Conflict of interest}

The author declared no potential conflict of interest with respect to research, authorship and/or publication of this article.

Received Date: 27-04-20; Revised Date: 28-05-20

Accepted Date: 04-06-20

\section{References}

1. ÖZEN H, COLOWICK A, FREIHA FS. Incidentally Discovered Solid Renal Masses: What Are They? Br J Urol. 1993;72(3):274-6.

2. Frank I, Blute ML, Cheville JC, Lohse CM, Weaver AL, Zincke H. Solid renal tumors: An analysis of pathological features related to tumor size. J Urol. 2003;170(6 I):2217-20.

3. Schlomer B, Figenshau RS, Yan Y, Venkatesh R, Bhayani SB. Pathological Features of Renal Neoplasms Classified by Size and Symptomatology. J Urol. 2006;176(4):1317-20.
4. Dechet CB, Zincke H, Sebo TJ, King BF, LeROY AJ, Farrow GM, et al. Prospective analysis of computerized tomography and needle biopsy with permanent sectioning to determine the nature of solid renal masses in adults. J Urol. 2003;169(1):71-4.

5. Wehle MJ, Grabstald H. Contraindications to needle aspiration of a solid renal mass: Tumor dissemination by renal needle aspiration. J Urol. 1986;136(2):446-8.

6. Jonasch E, Gao J, Rathmell WK. Renal cell carcinoma. BMJ. 2014;349:g4797.

7. Lee CT, Katz J, Shi W, Thaler HT, Reuter VE, Russo P. Surgical management of renal tumors $4 \mathrm{~cm}$. Or less in a contemporary cohort. J Urol. 2000;163(3):730-6.

8. Arora S, Aggarwal A, Singla P, Jyoti S, Tandon S. Anti-proliferative effects of homeopathic medicines on human kidney, colon and breast cancer cells. Homeopathy. 2013;102(4):274-82.

9. Allen HC. Allen's keynotes and characteristics with comparisons of some of the leading remedies of the materia medica with nosodes. B.Jain Publishers.2002

10. Ljungberg B, Cowan N, Hanbury DC, Hora M, Kuczyk MA, Merseburger AS, et al. Guidelines on renal cell carcinoma. Eur Urol. 2010;58(3): 398-406.

11. Kim HL, Belldegrun AS, Freitas DG, Bui MHT, Han K-R, Dorey FJ, et al. Paraneoplastic signs and symptoms of renal cell carcinoma: implications for prognosis. The journal of urology. 2003;170:1742-1746. 